$\xi=-1$

\title{
Mediatization of Politics as an Element of Noopolitics
}

\author{
Sergey Borisovich Nikonov, Nikolai Sergeevich Labush, Anatoli Stepanovich Puiy, Elena Savova Georgieva, Stani- \\ slav Sergeevich Lukin
}

Saint-Petersburg State University, 7/9 Universitetskay embankment, Saint-Petersburg, 199034, Russia

\begin{abstract}
The work deals with the study of information strategy, namely noopolitics. In the course of the work, it has been revealed that one of the elements of the information strategy formation is the need to mediatize political processes. The understanding of political processes mediatization is considered in the part devoted to the scientific research outcomes. The work also considers a phenomenon such as rumours. This is not fake news, which is so often mentioned by politicians, but political reality, which is also an element of noopolitics. The main part of the work deals with the results of the implementation of the noopolitics when preparing and carrying out presidential elections in 2018, and the role of foreign states and politicians in strengthening power in Russia.
\end{abstract}

Keywords: noopolitics, mediatization, political processes, Russian presidential elections, rumours.

\section{Introduction}

Mediatization of the political process, as well as noopolitics understood as the information strategy of the state on the manipulation of international processes continues to be studied by scientists from different perspectives. The study of the phenomenon of noopolitics has become, in fact, interdisciplinary. The issue of planning and determining the final goals has become one of the significant elements when shaping national policy. Planning issue defines the methods through which the state will pursue the implementation of its plans with respect to political process mediatization. Estonian researcher Maroš Krivý notes that "Planning as a political practice is superseded by an environmental-behavioural control, in which subjectivity is articulated supraindividually and infraindividually" [1].

Thus, a task is formed in which it is first necessary to determine the audience where the information will be disseminated, and the task, which consists in controlling the behavior of the audience in response to certain information attacks. After receiving feedback materials, it will be possible to form an information strategy. In this article, we do not disclose the methodology of information attacks, because the main purpose of the work is getting acquainted the reader with the results of the information operation aiming at manipulating international processes during the presidential elections in Russia (2018). In other words, we are talking about the mediatization of reality.

\section{Methods}

The work is based on the methods of political planning and forecasting, statistical analysis, comparative political analysis, content analysis, and perception analysis.

The method of statistical analysis determines the processing of an array of information appearing in the media about political events, and political decisions adopted and implemented in practice.
Methods of political planning and forecasting provide for the construction of forecast scenarios for the development of international relations depending on the information received through the media Other methods were used by the authors on an as-needed basis.

\section{Results}

Elections of the President of Russia took place on March 18, 2018. Everything went very well. The information strategy for manipulating international processes developed in Russia has shown its viability.

The US Senate, as well as the leaders of European States, have fully complied with their obligations to Russia. The task was not easy. It was necessary to publish fake news about Russia in the mass media all around the world to unite the Russian people around the current President of the Russian Federation. All experts understood that any negative information coming from any foreign mass media concerning Russia was perceived by citizens of Russia with mistrust. It is natural that both the United States and Europe realized that the more unreasonable was the criticism of V. Putin, the more people would protect him from the "attacks" of Western politicians.

In addition to the task of rallying the Russian people around V. Putin, there was another very important task to return exported capitals, derived, according to some Russian people, illegally during the presidency of B. Yeltsin and during the times when B. Nemtsov was the Chairman of the Russian Government. Precisely, these two leaders are credited with the agreement with the American establishment on the withdrawal of Russian capitals abroad. More than four years ago, Russian President V. Putin suggested Russian businessmen return their funds to Russia and place them in the Russian banking system. Not having received a convincing answer from the business, it can be argued with a high degree of probability that V. Putin instructed S. Lavrov, Russian Minister of Foreign Affairs, to offer a deal to European leaders and representatives of the Democratic Party of the United States. The essence of the deal, we believe, was as follows. A certain period was de- 
termined, as supposed, until the end of President Obama's term, after which Russian businessmen (mainly from the list of Forbs magazine) were to return "their" money capitals to Russia and pay certain taxes to the treasury of the Russian Federation. The state guaranteed that the rest of the money capitals would remain intact, while the criminal investigation into the illegality of the acquisition of these capitals in Russia would not be conducted.

In the United States, through certain lobbyists in the Senate, for example, such as J. McCain and H. Clinton, who, from the viewpoint of the American ordinary people, could not be attributed to the friends of Russia, the idea was advanced that the Russian Federation was to be blamed for all international events. At that, the lack of evidence of such declarations should be an indispensable prerequisite. In Russia, at that time, no one doubted that H. Clinton would win the US presidential election.

However, what has happened has happened. American electoral system allowed D. Trump to win the US presidential election.

But this anyhow did not change Russia's strategy to strengthen the power vertical in the country. During this period, as confirmed by the chronicle of events, political power in the United States was more owned by the US Senate than by the President. And if the US President did not have leverage over the Senate, his position was just a "beautiful" place.

So, D. Trump being elected as the US President had not held any full-scale official meeting with the President of Russia until the day of the election of V. Putin as President of Russia for a new term, for fear of accusations of support of the Russian President. And only after the election of V. Putin as President of Russia, it was officially announced that D. Trump had no contacts with Russia.

Meanwhile in Russia, in accordance with the developed information strategy - noopolitics in the mass media, information was disseminated that former members of the B. Yeltsin's team "robbed" Russian people during the time of his presidency. This information was not new, since ordinary citizens (the future electorate of V. Putin) knew this, because the actions of the persons, who withdrew their capitals from Russia, were in full public view. With a high degree of probability, due to the lack of instructions to law enforcement agencies from President B. Yeltsin, who was in power at that time, concerning the need to prevent such actions, the fight was not carried out against the "withdrawal of capital abroad". Moreover, as ordinary people considered, this was even encouraged. And the Great Britain, which was considered the financial center of Europe, became the main country, where financial capitals were transferred, and where Russian "oligarchs" moved, as well as foreign intelligence officers and "defectors" condemned for treason.

Thus, for example, such a concept as "noopolitics" has been developed, which is actively being studied by Russian scientists [2, 3 , $4,5,6]$.

It should be noted that noopolitics is an informational strategy of manipulating international processes through forming by means of mass media of positive or negative attitudes to the external or internal politics of a state or block of states, to create a positive or negative image of ideas and to promulgate moral values in the general public.

As mentioned above, the terms of the transaction have been respected. The US Senate has decided to create a list of Russian citizens, who have accounts in banks abroad, which at any time can be blocked and transferred to the US Treasury, since none of the Russians holding huge amounts of money at these accounts, will not be able to prove the legality of their receipt. Thus, Russia will have to pay the price for the agreement.

After the election of the President of Russia, according to the logic of the events, the Western States should start "hunting" for the bank accounts of the Russian oligarchs living abroad but not giving up Russian citizenship. It will be necessary to place information that the "oligarchs" are actually agents of foreign intelligence of Russia, which in fact cannot be ruled out.
This will again require the involvement of the mass media. The first edition, which had realized that it was being used, was Forbes magazine. In the article describing the situation, where Great Britain accused the Russian authorities of attacking Russian citizens located in the territory of Great Britain (the Skripal case), the author Vladislav Inozemtsev has described the events taking place, noticing in the actions of the British authorities pretty much the same "fake news" about the guilt of Russia. That's what Forbs writes "... on the other hand, these are some "general economic" problems that have long been discussed in Britain, but do not find a solution. First of all, we are talking about the fight against money laundering, in which any steps will certainly attract the interest of the Russian elite. In recent days, the debates have intensified on the possibility of banning the registration of any residential property except for private individuals (not so long ago it was done in Florida and New York, which allowed our anticorruption fighters easily discovering the apartments of officials and deputies in Miami)" [7]. We are talking about Russian officials and deputies.

The Russian mass media should closely monitor information on the work of law enforcement agencies in Western countries concerning sequestration of property of Russian oligarchs, officials, and deputies, and highlight these events in the Russian mass media. The forecast is obvious - the Russians will believe that the retribution has reached those, whom ordinary people in Russia consider thieves. Justice will be restored - albeit not in Russia, but abroad, and despite the fact that this money will go to the foreign budget, and not to the Russian one. And in Russia, for the majority of the population (the electorate), there is nothing more enjoyable than the restoration of justice.

\section{Discussion}

We can assert that in the theoretical aspect the information strategy is accessible to any state, but the opportunity to implement this strategy in terms of manipulating international processes, in our view, have just the states with real sovereignty, involving in the formation of a new world order.

Swedish scientists Jonathan Metzger, Linda Soneryd, and Kristina Tamm Hallström presented an article to the world community that would help in "...developing new theoretical and methodological resources for the analysis of power dynamics in planning studies. Our main goal is to demystify the concept of "power" and what it wants to describe, and to make this practice, grouped under this label, more tangible, and therefore also more easily contestable. Studying how effects are produced, which we call force, instead of using "power" as an all-encompassing explanation of social events, requires the conceptualization of power in the capacity of a result, and not as a cause variable behind them" [8].

The study of the effects of perception and dissemination of information in planning among the electorate is one of the most challenging tasks. Russian scientists Anna Baychik and Dmitry Gorbatov conducted research on the comparative analysis of the concepts of command and communication roles and considered strategies to counter false rumours. Paradoxically, but a special place in the formation of information strategy is given to false rumours and methods of countering false rumours. In consequence of their work, the authors studied the factors which were proposed by the American researcher R.L. Rosnow:

- general insecurity or the ubiquitous atmosphere of suspense, uncertainty, cognitive disorientation at the essence of the events;

- outcome-relevant involvement, the experience of personal connection with the projected outcome of what is happening;

- personal anxiety, acute or chronic emotional state caused by a presentiment of disappointing consequences;

- credulity or trust to message, a belief in its complete or at least partial compliance with reality [9].

Gorbatov D. and A. Baychik came to the conclusion that only a combination of noted factors rather than each of them separately 
can now serve a strategic guide for the selection of specific methods for countering false rumours $[10,11]$.

Having considered a sufficient amount of content of Russian, American and English media, we can come to the conclusion that publications on international issues are covered exactly by the above-mentioned factors, that is, there is mediatization of the political process.

Discoverability, efficiency in the formulation of attitudes, the ability to reflect a wide range of interests and requests of different groups of the population allow the mass media to influence the political process, modify its structure and orientation, "reconfigure" the rules of the political game. The mass media create a platform for open discussion, struggle of opinions, ideas and programs, retaining the right to make a verdict or adjusting the final judgment of the mass audience on one or another political issue.

Presenting political events into the entertaining and captivating image, journalists are able to turn political conflicts from a tough fight into a show, the performance that does not have real meaning for the actual life of citizens. Conversely, focusing on the need of mass consciousness of citizens in news, the mass media are able to create, invent events that were not happening in reality, to give them a sensational character, to draw attention to those events which will form the agenda in the future.

Special attention of modern researchers is focused on the process of mediatization, which is primarily due to the increased impact of the mass media on the political process, the possibility of using the characteristics of social information to influence the formation of public opinion of a given characteristic and social focus.

From the very beginning, the term "mediatization" was used to describe a special technical and technological infrastructure designed to provide individual and collective access to all the spiritual values of information civilization. A quite broad comprehension of media is presented by the culture experts, who attribute to the mass media all intermediaries, the application of which introduces significant changes in human communication with the surrounding world (both natural and social), as well as reorganizes its way of perceiving the world and way of life. According to scientists, these include different phenomena such as electric light, oral speech, writing, roads, numbers, clothing, housing, city, money, clock, publications, comics, book, advertising, wheel, vehicles, automatic equipment, photography, games, press, telegraph, typewriter, telephone, phonograph, cinema, radio, television, weapons, and much more [12].

At a later stage, some sociologists, legislators, and researchers of mass communication systems began to use this term when describing the formation process of a special type of social space, calling it "mediatization of society".

Based on the concept of "intermediacy", i.e. mediation, mediatization reflects the social transformation process. The "mediatization" category has its own interpretation peculiarities in relation to this or that environment.

From the standpoint of social informatics, I.V. Sokolova defines mediatization as the process of improving the means of collecting, storing, and disseminating information. Implementation and support of these processes in the society is the major function of the mass media, mass communication, and the whole media environment [13]. Linguist N.I. Klushina considers "the spread of media influence on the most important areas of social life and the reverse process of involvement of various aspects of social activity into the information sphere, that is, the creation of zones of the intersection of media and social phenomena" [14].

According to V.Yu. Perezhogin, mediatization represents a process of informatization, the purpose of which is the creation and dissemination of most advanced systems of collective and personal communication, providing ultimately access of any member of society to all sources of information and his entry into the world of virtual realities [15].

An original view with respect to this process can be found in the works of Slavoj Zižek, who considers modern culture in the con- text of overall mediatization, i.e. the process of turning a real object into an artificial one: "a body that is almost completely "mediatized" operates by means of prostheses and speaks in an artificial voice" [16]. In the course of the mediatization of the body, human consciousness changes as well, while the person captured and immersed in media culture becomes a product of new media. In this process, media represent a very specific and powerful "matrix" - a system of cultural and information monopolies, which now becomes the major pillar of any state.

Some researchers rightly distinguish the manipulative essence of the mediatization processes. Thus, L.M. Zemlyanova emphasizes that "in communication studies, mediation is associated with the mediating role of mass media, which find out the essence of conflicts, contribute or hinder their resolution based on information analysis. The concept of mediation can be interpreted as a manifestation of the transforming function of the mass media, which in the course of accumulation, processing ("filtering") and transmission of information about the facts of reality are able to modify them (or to distort), giving them mediated meanings, arising in the course of fabricating imaginary images (events) of reality. To emphasize the intensity of their influence on public consciousness and being, on the fate of culture, researchers, who criticize such type processes, use the term... mediatization" [17].

The category of "mediatization" has its own peculiarities of interpretation with regard to this or that environment. Mediatization of reality is a theory that states that media influence not only social and political processes but also the society in which they take place. Changes in the communication mass media have led to changes in the basic institutions of society. Therefore, the development of media is an important factor in the modernization of society. Based on the concept of "mediation", mediatization reflects the process of social transformation.

With regard to politics and the mass media, the term of mediatization has begun to be applied relatively recently. Swedish media researcher Kent Asp comprehends mediatization as a phenomenon in which the political system is influenced by the mass media and corrected by the mass media through the manner of covering political events. Using this term $\mathrm{K}$. Asp tried to explain how media became a necessary intermediary between politicians and society. Moreover, the political structure becomes dependent on the mass media when they are the only source of political information, through which it can influence people's perceptions of political reality.

Mass media specialists suggest that mediatization is a social process in which society is so oversaturated with media that other phenomena can no longer exist separately from the mass media.

The starting point of the reasoning concerning the essence of politics mediatization can serve, firstly, the definition of politics as relations among large groups of people associated with the strength of power, secondly, the understanding of power as the ability and opportunity of one entity to impose its will on another entity, and, thirdly, the idea of democracy as the power of the people. Without going into arguments about the connection and interdependence of these phenomena, it is important to note that they, like other social processes and phenomena, proceed and exist by dint of information and on the basis of information. Therefore, it is natural that the mass media, or simply media are a tool by which communications of social groups are carried out through the power, a tool by which one can impose the will of one subject to another, and a tool, by which one can substantially or at least formally grant everyone the right to rule - "Demos Kratos".

In the course of long-term development, social being is replaced by private media, while the democracy of the masses through the mediatization of politics becomes the democracy of audiences.

But the mediatization of politics, which has prerequisites at the "paper" stage, unfolds precisely through the instrumentality of electronic mass media, creating a virtual space in which it is possible to carry out the charismatic type of domination on the basis of new technologies. It is obvious that the onset of each subsequent stage in the development of political communication does 
not mean the disappearance of the previous forms. In modern conditions, each of them has its own characteristics and advantages, and different opportunities for mediatization of politics. Describing the essence of mediatization, it is not enough understanding this process as just the increase in the proportion of political broadcasts on radio and television, which has a much more significant impact on the audience than the real actions of the actors of the political space. The real policy becomes impossible without the involvement of this broad audience through the mass media. Therefore, to a greater extent, the mediatization is characterized by the figuration of the "political-journalistic field" and "consistent movement of the heaviness of political space" [18] towards attracting mass audience through the content, which is carefully built and cleaned out in accordance with a certain logic and maximally "consumed" by the audience.

"The distinguishing feature of our time is that the mass media, telling about politics, have become the only source of reflection of political events, regardless of place and time. It is the mass media that increase or decrease the significance of what has happened in the country or the world, limiting this space to a set of positions and images, and designing a mediatized politics. In other words, there is a process of shifting political meanings and aspects from reality to virtuality. Imaginary constructs are increasingly influencing real political processes, not only substituting reality but actively shaping it" [19].

The development of communication and information technologies has opened new forms and possibilities of interaction between politics and the mass media, as well as the inter-influence of political and media fields on each other. It is on the political field that there is a continuous struggle for the power of creating reality through words, for the power to focus public attention on certain issues, and the removal of inconvenient topics from the agenda. For this reason, the entire abstract architecture of the political field is based on the mass media.

Therefore, contemporary researchers of mediatization define it through "an aggregate of processes and phenomena of information influence and interaction within both the political sphere (by means of formal or informal managerial technologies) and its intertwining with the mass media sphere, that is, through public presentations of political meanings" [20].

Mediatized politics is the virtual reality that is presented and created by the mass media, while the politics mediatization is the process of establishing this reality. It is an aggregate of mass phenomena of information influence and interaction within both the political sphere (by means of formal or informal managerial technologies), and the intertwined sphere of mass media, which allows talking about the mediatization of politics and the formation of the media-based political system [21]).

\section{Conclusion}

The modern era is characterized by the fact that the mass media, which represent politics, are the defining and sometimes the only way to represent the political reality, regardless of the time and place of occurring events. As a result, the mass media has become one of the most important actors in the political field. This is because, firstly, the information that is brought by the mass media to the public space becomes the only common point with politics for the overwhelming majority of society. And secondly, because there are clear structural connections between the media system and the political system: politics benefits from the presence in the media, while media require a political response for this presence.

One can agree with the viewpoint of E.A. Voinova that, as a rule, mediatization of politics is considered, firstly, in cases where it is necessary underlining that agents can establish communication and make people perceiving themselves in the political field just through the media, since only media contribute to giving meaning to the political events and provide the essence to facts in the public space. And secondly - "when it is necessary to indicate the need, possibility and activity of certain subjects of the political process, seeking to replace the real political action and bilateral communication with their imitation in the media space exclusively by means of one-sided media construct" [22]. And just in this interpretation the concept of "media politics" is one of the most important for understanding the features of the modern political process.

The degree of full-fledged and reliable reflection in the mass media of one or another event objectively depends on the physical capabilities of reproduction of real events, the professional skills of journalists to create a media "picture" most adequate to the real pattern, and some other circumstances. That is, the virtuality created in the course of mediatization is not able to fully, comprehensively, and completely reflect the reality. The subjective side is hidden in the intentions of the journalist, editorial board, and political force, whose will be supported by the journalist, and consists in the conscious change/distortion of the created virtuality. It is in this totality of objective and subjective side that the peculiarity of politics mediatization is revealed. Modern researchers focus on the study of this very subjective side, bearing in mind that, firstly, political actors can add themselves the "weight" in the political field using mass media, because the media have the ability to enhance the value of individual events and phenomena, or, conversely, to ignore, filtering them out. And, secondly, there is a need and the capability of the political process actors, who seek to replace real political action by its imitation in the media space, substituting the meaning of the information by simplistic, neutral, or entertaining presentation using exclusively media-based construct of political reality. Outwardly, mediatization is often perceived rather superficially. Politics is given more spectacularity and personalization, while politicians seek to get into the center of events and become a media person.

\section{References}

[1] M. Krivý, Towards a critique of cybernetic urbanism: The smart city and the society of control, Planning Theory 17(1) (2018) 8-30.

[2] S.B. Nikonov, Information society in its function as an object of directed influence of noopolitics, World Applied Sciences Journal 27(13A) (2013) 241-246

[3] S.B. Nikonov, Noopolitical aspect of international journalism, Middle-East Journal of Scientific Research 17(1) (2013) 21-25.

[4] S.B. Nikonov, A.V. Baichik, R.V. Zaprudina, N.S. Labush, A.S. Smolyarova, Noopolitics and information network systems, International Review of Management and Marketing 5 (2015) 44-48.

[5] S.B. Nikonov, V.A. Achkasova, N.S. Labush, A.V. Baichik, A.S Puiy, Noopolitic as an information strategy: Genesis of the conceptual apparatus and definition, Man in India 96(10) (2016) 41294138.

[6] N.S. Labush, S.B. Nikonov, S.B., A.S. Puiy, E.S. Georgieva, R.V. Bekurov, War and armed conflict in the information space, International Review of Management and Marketing 5 (2015) 30-35.

[7] V. Inozemtsev. Vojna po raspisaniyu: chto znachit dlya Kremlya okrik iz Londona [Scheduled war: What does hail from London mean for the Kremlin]. http://www.forbes.ru/biznes/358615-voyna-po-raspisaniyu-chtoznachit-dlya-kremlya-okrik-iz-

londona\#0_5_3637_13035_1240_183652268. Revised March 15, 2018. Accessed July 5, 2018.

[8] J. Metzger, L. Soneryd, K.T. Hallström, Power is that which remains to be explained: Dispelling the ominous dark matter of critical planning studies, Planning Theory 16(2) (2017) 203-222.

[9] R.L. Rosnow, Inside rumor a personal journey, American Psychologist 46(5) (1991) 484-496. DOI: 10.1037/0003066X.46.5.484.

[10] D.S. Gorbatov, A.V. Baychik, Sravnitel'nyj analiz koncepcij komandnyh i kommunikacionnyh rolej [Comparative analysis of the concepts of command and communication roles], Scientific research and development, Socio-humanitarian research and technology 6(3) (2017) 21-27.

[11] D.S. Gorbatov, V.A. Baychik, Strategiya protivodejstviya lozhnym sluham: teoreticheskij analiz [Strategy to counter false rumors: A 
theoretical analysis], Russian Psychological Journal 14(2) (2017) 185-201.

[12] M. McLuhan, Understanding media: The extensions of Man, 1964.

[13] I.V. Sokolova, Social'naya informatika [Social informatics], Perspective. Russian State Social University, Moscow, 2008.

[14] N.I. Klushina, Mediatizaciya sovremennoj kul'tury i russkij nacional'nyj stil' [Mediatization of modern culture and Russian national style], Russian Speech 1 (2014) 69.

[15] V.Yu. Perezhogin, Identifikaciya informacionnyh rezervov povysheniya kachestva produkcii i uslug kommercheskoj organizacii [Identification of information reserves to improve the quality of products and services of a commercial organization], Tambov State Technical University, Tambov, 2007

[16] S. Zizek, Kiberprostranstvo, ili Nevynosimaya zamknutost' bytiya [Cyberspace, or the unbearable closure of being], The Art of Cinema, 1998.

[17] L.M. Zemlyanova, Mediatizaciya kul'tury i komparativizm v sovremennoj kommunikativistike [Mediatization of culture and comparativism in modern communication studies], Bulletin of Moscow University, Journalism 10(5) (2002).

[18] P. Champagne, Delat' mnenie: novaya politicheskaya igra [Make an opinion: A new political game], Socio-Logos, Moscow, 1997.

[19] L.V. Kazimirchikm, Fenomen mediatizacii publichnoj politiki: teoretiko-metodologicheskij aspekt [The phenomenon of public policy mediatization: Theoretical and methodological aspect], Theory and Practice of Social Development 11 (2004) 99-100.

[20] E.A. Voinova, Mediatizaciya politiki kak fenomen novoj informacionnoj kul'tury [Mediatization of politics as a phenomenon of new information culture], Moscow, 2006.

[21] I.I. Zasursky, Mass-media vtoroj respubliki [Mass media of the second Republic]. Moscow State University Publishing House, Moscow, 2011

[22] E.A. Voinova, Mediatizirovannaya politicheskaya kommunikaciya: sposob medijnogo iskazheniya politiki ili sposob organizacii diskursa? [Mediatized political communication: Media distortions of politics or method of organizing discourse?], Bulletin of Moscow University, Journalism 10(6) (2006). 